\title{
Enhanced-Efficiency Fertilizers in Nitrous Oxide Emissions from Urea Applied to Sugarcane
}

\author{
Johnny R. Soares, Heitor Cantarella, ${ }^{*}$ Vitor P. Vargas, Janaina B. Carmo, Acácio A. Martins, \\ Rafael M. Sousa, and Cristiano A. Andrade
}

\begin{abstract}
The environmental benefits of producing biofuels from sugarcane have been questioned due to greenhouse gas emissions during the biomass production stage, especially nitrous oxide $\left(\mathrm{N}_{2} \mathrm{O}\right)$ associated with nitrogen $(\mathrm{N})$ fertilization. The objective of this work was to evaluate the use of nitrification inhibitors (NIs) dicyandiamide (DCD) and 3,4 dimethylpyrazole phosphate (DMPP) and a controlled-release fertilizer (CRF) to reduce $\mathrm{N}_{2} \mathrm{O}$ emissions from urea, applied at a rate of $120 \mathrm{~kg} \mathrm{ha}^{-1}$ of N. Two field experiments in ratoon cycle sugarcane were performed in Brazil. The treatments were (i) no N (control), (ii) urea, (iii) urea+DCD, (iv) urea+DMPP, and (v) CRF. Measurements of $\mathrm{N}_{2} \mathrm{O}$ fluxes were performed using static chambers with four replications. The measurements were conducted three times per week during the first $3 \mathrm{mo}$ and biweekly afterward for a total of 217 and $382 \mathrm{~d}$ in the first and second seasons, respectively. The cumulative $\mathrm{N}_{2} \mathrm{O}-\mathrm{N}$ emissions in the first ratoon cycle were $1098 \mathrm{~g} \mathrm{ha}^{-1}$ in the control treatment and $1924 \mathrm{~g} \mathrm{ha}^{-1}$ with urea ( $0.7 \%$ of the total $\mathrm{N}$ applied). Addition of NIs to urea reduced $\mathrm{N}_{2} \mathrm{O}$ emissions by more than $90 \%$, which did not differ from those of the plots without N. The CRF treatment showed $\mathrm{N}_{2} \mathrm{O}$ emissions no different from those of urea. The results were similar in the second ratoon: the treatment with urea showed $\mathrm{N}_{2} \mathrm{O}$ emissions of $0.75 \%$ of $\mathrm{N}$ applied $\mathrm{N}$. Application of NIs resulted in a strong reduction in $\mathrm{N}_{2} \mathrm{O}$ emissions, but CRF increased emissions compared with urea. We therefore conclude that both NIs can be options for mitigation of greenhouse gas emission in sugarcane used for bioenergy.
\end{abstract}

\footnotetext{
Copyright $\odot$ American Society of Agronomy, Crop Science Society of America, and Soil Science Society of America. 5585 Guilford Rd., Madison, WI 53711 USA. All rights reserved. No part of this periodical may be reproduced or transmitted in any form or by any means, electronic or mechanical, including photocopying, recording, or any information storage and retrieval system, without permission in writing from the publisher.
}

J. Environ. Qual. 44:423-430 (2015)

doi:10.2134/jeq2014.02.0096

Freely available online through the author-supported open-access option.

Received 28 Feb. 2014.

*Corresponding author (cantarella@iac.sp.gov.br).
$\mathrm{S}$ UgARCANE ETHANOL has been recognized as environmentally friendly due to the reduction of greenhouse gas (GHG) emissions when it replaces fossil fuel (Boddey et al., 2008; Galdos et al., 2010; Lisboa et al., 2011). However, nitrous oxide $\left(\mathrm{N}_{2} \mathrm{O}\right)$ emission associated with $\mathrm{N}$ fertilization during biomass production can offset these benefits (Crutzen et al., 2008).

In Brazil, $\mathrm{N}_{2} \mathrm{O}$ is the most important GHG emitted from agricultural soils (Cerri et al., 2009; MCTI, 2013). The global warming potential of $\mathrm{N}_{2} \mathrm{O}$ is 298 times greater than $\mathrm{CO}_{2}$ over a 100 -yr period. In addition, $\mathrm{N}_{2} \mathrm{O}$ is the main source of nitric oxide, which causes depletion of the stratospheric ozone layer (IPCC, 2007).

The default value for $\mathrm{N}_{2} \mathrm{O}$ emitted by $\mathrm{N}$ fertilizers is $1 \%$ of the $\mathrm{N}$ applied (IPCC, 2006), but the actual percentage can vary. Crutzen et al. (2008) reported emission factors of 3 to $5 \%$ of the total $\mathrm{N}$ applied. Lisboa et al. (2011), compiling data from Australia, Hawaii, and Brazil, suggested a mean emission factor of 3.9\% of $\mathrm{N}$ applied in sugarcane fields. Although background values were not discounted, these $\mathrm{N}_{2} \mathrm{O}$ emissions may represent $40 \%$ of the total GHG emission for systems in which ethanol is produced from sugarcane (Lisboa et al., 2011). In Brazil, Carmo et al. (2013) found that the proportion of $\mathrm{N}$ emitted can be influenced by sugarcane trash retention and averaged $1.1 \%$ of $\mathrm{N}$ applied. However, when vinasse, a residue of ethanol production, was applied, the $\mathrm{N}$ fertilizer emission factor increased to $3 \%$. In two other regions in Brazil, Signor et al. (2013) reported higher losses of $\mathrm{N}_{2} \mathrm{O}$ in sugarcane fields than those reported by Carmo et al. (2013).

Emissions of $\mathrm{N}_{2} \mathrm{O}$ in soils mainly occur due to nitrification and denitrification processes (Stevens and Laughlin, 1998). Many factors are involved in estimating the amount of $\mathrm{N}_{2} \mathrm{O}$ emitted, including (i) management practices (e.g., fertilizer source, rate, placement, timing, other chemicals, crop, irrigation, presence of plant residues) and (ii) environmental and soil factors (e.g., temperature, rainfall, soil moisture, organic C, oxygen

\footnotetext{
J.R. Soares, H. Cantarella, V.P. Vargas, A.A. Martins, and R.M. Sousa, Soils and Environmental Resources Center, Agronomic Institute of Campinas, P.O. Box 28, 13012-970, Campinas, SP, Brazil; J.B. Carmo, Environmental Science Dep., Federal Univ. of São Carlos, 1852-780, Sorocaba, SP, Brazil; C.A. Andrade, Embrapa Environment, 13820-000, Jaguariúna, SP, Brazil. Assigned to Associate Editor Eric Davidson.

Abbreviations: CRF, controlled release fertilizer; DCD, dicyandiamide; DMPP, 3,4-dimethylpyrazole phosphate; EEF, enhanced-efficiency fertilizers; GHG, greenhouse gas; NI, nitrification inhibitor; PSCU, polymer and sulfur-coated urea; UR, urea.
} 
concentration, porosity, $\mathrm{pH}$, and microorganisms) (Carmo et al., 2013; Eichner, 1990; Snyder et al., 2009; Vargas et al., 2014).

One way to reduce $\mathrm{N}_{2} \mathrm{O}$ emissions due to the use of $\mathrm{N}$ fertilizers is by the addition of nitrification inhibitors (NIs). Nitrification inhibitors maintain $\mathrm{N}$ in soil in the $\mathrm{NH}_{4}^{+}$form for a period of time by suppressing microbial oxidation of ammonium (Subbarao et al., 2006). The crop may then take up $\mathrm{NH}_{4}^{+}-\mathrm{N}$, reducing $\mathrm{N}_{2} \mathrm{O}$ emission due to nitrification and denitrification (Hu et al., 2013; Liu et al., 2013; Snyder et al., 2009). Several NIs are commercially available, including nitrapyrin, dicyandiamide (DCD), and 3,4-dimethylpyrazole phosphate (DMPP) (Trenkel, 2010).

Controlled-release fertilizers (CRFs) also can reduce $\mathrm{N}_{2} \mathrm{O}$ emissions. Akiyama et al. (2010) compiled data from 35 studies to evaluate CRF effects in $\mathrm{N}_{2} \mathrm{O}$ emissions and found an overall reduction of $35 \%$ compared with conventional and organic sources of $\mathrm{N}$. The $\mathrm{N}$ release synchronized with plant demand can increase $\mathrm{N}$ use efficiency and thereby reduce $\mathrm{N}_{2} \mathrm{O}$ emissions (Hyatt et al., 2010; Yang et al., 2012). Controlledrelease fertilizers have small market participation because of high prices, but their importance has increased due to agronomic and environmental benefits (Chien et al., 2009).

Nitrification inhibitors and CRFs are recognized as options of GHG mitigation. IPCC (2001) assumes an average reduction of $30 \%$ in $\mathrm{N}_{2} \mathrm{O}$ emissions when NI and CRFs are used. However, higher reductions have been reported. Snyder et al. (2009) listed studies with reductions between 40 and $90 \%$ by addition of NIs to conventional fertilizers. However, the extent of the effect of NIs is not clear, especially in warm tropical soils. No study has been done to compare the efficiency of NIs and CRFs in sugarcane used for bioenergy in Brazil, the largest producer in the world, with 9 million ha cultivated with this crop. Sugarcane is a long-cycle crop, with very high biomass production, grown in tropical and subtropical conditions that may affect $\mathrm{N}_{2} \mathrm{O}$ emissions from $\mathrm{N}$ fertilizer. Therefore, the aim of this study was to evaluate the efficiency of DCD, DMPP, and CRFs in reducing $\mathrm{N}_{2} \mathrm{O}$ emissions from urea applied to sugarcane.

\section{Materials and Methods}

Three enhanced-efficiency fertilizers were tested. The treatments were: (i) no $\mathrm{N}$ (control), (ii) urea (UR), (iii) UR+DCD, (iv) UR+DMPP, and (v) polymer and sulfurcoated urea (PSCU), a CRF. The fertilizers were evaluated in two consecutive cycles, under field conditions, in ratoon cane in 2011/2012 and 2012/2013. In the second ratoon cycle, the treatments were applied in the same plots, but two additional treatments were included (UR+DCD and $U R+D M P P)$ in new plots in the same field to test the hypothesis that NIs could be less efficient if reapplied in the same area.

Sugarcane yields were not measured because gaseous $\mathrm{N}$ losses as $\mathrm{N}_{2} \mathrm{O}$ are relatively small, and no $\mathrm{NH}_{3}$ volatilization was expected in this study because urea was incorporated into the soil. Leaching losses, which could be reduced by the NI or CRF treatments, are considered to be of little significance for sugarcane grown in the southeastern region of Brazil (Ghiberto et al., 2009, 2011). To minimize soil variability and to focus on the GHG evaluations, the treatments were concentrated in a small area of a sugarcane field with a uniform plant stand.

The experiment was installed in a sugarcane field grown with the variety SP791011, spaced $1.5 \mathrm{~m}$ between rows, at Agronomic Institute in Campinas, Brazil $\left(22^{\circ} 52^{\prime} 15^{\prime \prime} \mathrm{S}, 47^{\circ} 04^{\prime} 57^{\prime \prime} \mathrm{W}\right)$. The soil is classified as a Typic Hapludox or Red Latosol (Empresa Brasileira de Pesquisa Agropecuária, 2006). The chemical (van Raij et al., 2001) and physical properties (Camargo et al., 1986) of the 0 - to $20-\mathrm{cm}$ layer are shown in Table 1.

The experimental units were $1-\mathrm{m}$ sections of sugarcane rows with a gas chamber installed in the middle of the fertilizer band. It was assumed that the chemical and biological reactions that cause $\mathrm{N}_{2} \mathrm{O}$ emissions take place in a small soil area; large plots would not bring additional benefit because of the high spatial variability of $\mathrm{N}_{2} \mathrm{O}$ emissions in soils (Mathieu et al., 2006). The experiment followed a complete randomized design with four replications, resulting in 20 plots and 20 chambers.

Fluxes of $\mathrm{N}_{2} \mathrm{O}$ were measured using PVC static chambers, 20 $\mathrm{cm}$ in height and $30 \mathrm{~cm}$ in diameter, according to the method used by Rochette and Ericksen-Hamel (2008) and Carmo et al. (2013). The chambers were inserted $5 \mathrm{~cm}$ into the soil and $10 \mathrm{~cm}$ from the sugarcane rows.

The $\mathrm{N}$ fertilizer treatments were applied at rate of $120 \mathrm{~kg} \mathrm{ha}^{-1}$, which is in the range of recommendations for sugarcane in Brazil (van Raij et al., 1997). Lime, phosphorus, potassium, sulfur, zinc, and boron were common to all plots and were applied separately from the $\mathrm{N}$ fertilizer treatments.

The NIs were added to UR in the laboratory at Agronomic Institute. Analytical-grade DCD (Sigma Aldrich) in powder form containing $650 \mathrm{~g} \mathrm{~kg}^{-1}$ of $\mathrm{N}$ was weighed individually and mixed with urea for each plot at a rate corresponding to $5 \%$ of DCD-N in relation to urea-N (Soares et al., 2012; Subbarao et al., 2006; Weiske et al., 2001). The DMPP, also analytical grade and in powder form, was used at a rate of $1 \%$ in relation to urea- $\mathrm{N}$ (Liu et al., 2013; Subbarao et al., 2006; Weiske et al., 2001).

Polymer sulfur-coated urea ( $390 \mathrm{~g} \mathrm{~N} \mathrm{~kg}^{-1}$ and $110 \mathrm{~g} \mathrm{~S} \mathrm{~kg}^{-1}$ ) (Produquimica) has two coating layers composed of elemental sulfur and water-insoluble, polyacrylate-derived resin.

Table 1. Properties of the $0-$ to $20-\mathrm{cm}$ layer of the Red Latosol of the experimental area.

\begin{tabular}{|c|c|c|c|c|c|c|c|c|c|c|}
\hline \multirow{2}{*}{$\begin{array}{c}\mathrm{pH} \\
\left(\mathrm{CaCl}_{2} ; 0.0125 \mathrm{~mol} \mathrm{~L}^{-1}\right)\end{array}$} & \multirow{2}{*}{ OC } & \multirow{2}{*}{$\mathrm{P} \neq$} & \multirow{2}{*}{$\mathrm{K}$} & \multirow{2}{*}{$\mathrm{Ca}$} & \multirow{2}{*}{$\mathrm{Mg}$} & \multirow{2}{*}{$\mathrm{H}+\mathrm{Al}$} & \multirow{2}{*}{ CECף } & \multicolumn{3}{|c|}{ Soil texture\# } \\
\hline & & & & & & & & Clay & Silt & Sand \\
\hline & $\mathrm{gdm}^{-3}$ & $\mathrm{mg} \mathrm{dm} \mathrm{m}^{-3}$ & & 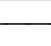 & $\mathrm{nol}_{\mathrm{c}} \mathrm{c}$ & 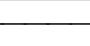 & - & $\longrightarrow$ & $\mathrm{g} \mathrm{kg}^{-}$ & 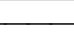 \\
\hline 5.6 & 12 & 8 & 2.7 & 22 & 12 & 19 & 55.9 & 410 & 175 & 415 \\
\hline
\end{tabular}

† Organic carbon (oxi-reduction).

₹ Phosphorus, $\mathrm{K}, \mathrm{Ca}$, and $\mathrm{Mg}$ were extracted with ion exchange resin.

$\S$ Buffer solution ( $\mathrm{pH} 7.0$ ).

I Cation exchange capacity.

\# Soil texture determined by the densimeter method. 
The trash left after the harvest of the previous sugarcane crop was removed from the field to simulate plant residue collection for energy production. In the second year, little trash remained in the soil because the cane had been burned before harvest.

To prevent $\mathrm{NH}_{3}$ volatilization, the fertilizers were banded and incorporated to the soil in a small furrow made with a hoe, about $5 \mathrm{~cm}$ deep, because NIs can increase $\mathrm{NH}_{3}$ losses from urea (Soares et al., 2012) and could cause an underestimation of $\mathrm{N}_{2} \mathrm{O}$ emissions (Snyder et al., 2009). The fertilizer band was parallel to and distant around $0.2 \mathrm{~m}$ from the sugarcane row, as is commonly done in sugarcane fields in Brazil. The spot in the middle of the fertilized band where the chambers for GHG measurement were placed ( $0.3 \mathrm{~m}$ in diameter) received individually weighed amounts of the fertilizer treatments, also incorporated at $5 \mathrm{~cm}$, so that the $\mathrm{N}_{2} \mathrm{O}$ emission factor could be directly calculated:

$$
\mathrm{N}_{2} \mathrm{O}-\mathrm{N} \text { factor }=\frac{\mathrm{N}_{2} \mathrm{O}-\mathrm{N}_{\text {treat. }}-\mathrm{N}_{2} \mathrm{O}-\mathrm{N}_{\text {control }}}{\mathrm{N}_{\text {applied }}}
$$

where $\mathrm{N}_{2} \mathrm{O}-\mathrm{N}_{\text {treat. }}$ and $\mathrm{N}_{2} \mathrm{O}-\mathrm{N}_{\text {control }}$ are the cumulative emissions of the fertilized and unfertilized chambers, respectively, and $\mathrm{N}_{\text {applied }}$ is the mass of $\mathrm{N}$ fertilizer added to the chamber. The whole field $\mathrm{N}_{2} \mathrm{O}$ emission was calculated using the background $\mathrm{N}_{2} \mathrm{O}$ emission data obtained from the unfertilized chambers and data of the fertilizer treatments. The fertilized area corresponded to $16 \%$ of the total area, equivalent, for every sugarcane row, to a strip of land $0.3 \mathrm{~m}$ wide (i.e., the width of the chamber corrected for the chamber's actual circular area). Conversely, $84 \%$ of the field was assumed to have just the background emission.

Gas samples were collected in the mornings (Alves et al., 2012) three times per week for the first 3 mo after fertilizer application. Subsequently, the sampling was done weekly or biweekly. For the samplings, the chambers were closed with a 7-cm cap. The caps have two openings, each fitted with a valve, one for gas sampling and other to equilibrate internal and external pressure. Gases were sampled with plastic syringes $(60 \mathrm{~mL})$ at three time intervals $(1$, 15 , and $30 \mathrm{~min}$ ) after the chambers were closed (Mosier et al., 2006). The samples were transferred and stored in pre-evacuated Exetainers vials $(12 \mathrm{~mL})$. During each gas sampling, air and soil temperature and atmospheric pressure were measured. Climatic data were obtained from a meteorological station located $300 \mathrm{~m}$ from the experiment.

The samples were analyzed in a gas chromatograph (model GC-2014, Shimadzu Co.) with an electron capture detector for $\mathrm{N}_{2} \mathrm{O}$ determination (Hutchinson and Mosier, 1981). Nitrous oxide flux was calculated by linear interpolation of the three sampling times. Daily $\mathrm{N}_{2} \mathrm{O}$ fluxes were plotted using Sigma Plot software, version 10 (Systat Software, 2006). Cumulative emissions were calculated by linear interpolation between adjacent sampling dates (Allen et al., 2010). Total cumulative emission was submitted to ANOVA, and means were compared (Tukey $p \leq 0.05$ ) using SISVAR statistical software.

In the first cycle, GHG measurements were conducted for a total of $217 \mathrm{~d}$ from April 2012 to November 2012, when the cane was harvested. In the second cycle, the evaluation period was 382 d, from November 2012 to November 2013. In the 2011/2012 cycle, the fertilizer treatments were applied in April in a ratoon crop, where plants were approximately $1.5 \mathrm{~m}$ tall. The previous cycle (cane plant) was harvested in December 2011. Therefore, the $\mathrm{N}$ fertilization was done 4 mo after harvest, later than recommended for this region (van Raij et al., 1997). After an accidental fire, the cane of the 2011/2012 cycle was harvested in November 2012. For the 2012/2013 cycle, the treatments were applied $15 \mathrm{~d}$ after the harvest. At this time point, the cane plants were smaller $(0.5 \mathrm{~m})$ than in $2011 / 2012$.

\section{Results}

The climatic conditions of the experimental period are shown in Fig. 1 and 2. Mean air temperature varied between 15 and $30^{\circ} \mathrm{C}$, and total rainfall amounts were 540 and $1255 \mathrm{~mm}$ in the first and second seasons, respectively.

In the 2011/2012 cycle, the dry period was typical of the south-central region of Brazil. From July until September (100$165 \mathrm{~d}$ after fertilizer application), total rain precipitation was $<30 \mathrm{~mm}$ (Fig. 1). The 2012/2013 season was wetter than average. Rainfall in the dry and cool period from May to October (170$311 \mathrm{~d}$ after fertilizer application) was $239 \mathrm{~mm}$ (Fig. 2).

Emissions of $\mathrm{N}_{2} \mathrm{O}$ were low in the first $10 \mathrm{~d}$ after fertilizer application in $2011 / 2012\left(<5 \mathrm{~g} \mathrm{ha}^{-1} \mathrm{~d}^{-1}\right.$ of $\left.\mathrm{N}\right)$ (Fig. 1). The treatment with urea had a peak $\mathrm{N}_{2} \mathrm{O}$ emission on the 17 th day, corresponding to $70 \mathrm{~g} \mathrm{ha}^{-1} \mathrm{~d}^{-1}$ of $\mathrm{N}$. After this, two other emission peaks ( 40 and $30 \mathrm{~g} \mathrm{ha}^{-1} \mathrm{~d}^{-1}$ ) occurred after rain events; between these peaks, the $\mathrm{N}_{2} \mathrm{O}-\mathrm{N}$ emissions were approximately $15 \mathrm{~g} \mathrm{ha}^{-1} \mathrm{~d}^{-1}$. The treatments with NIs had smaller $\mathrm{N}_{2} \mathrm{O}$ fluxes, similar to the control treatment, which was around $5 \mathrm{~g} \mathrm{ha}^{-1} \mathrm{~d}^{-1}$ of $\mathrm{N}$. Polymer and sulfur-coated urea showed lower $\mathrm{N}_{2} \mathrm{O}$ emission (30 $\mathrm{g} \mathrm{ha}^{-1} \mathrm{~d}^{-1}$ ) than conventional urea on the 17 th day, but in the other two peaks, 60 and $80 \mathrm{~d}$ after fertilizer application, the emissions were similar to those of urea (Fig. 1).

In the period between 80 and $160 \mathrm{~d}$ after fertilizer application, emissions in all treatments were low, compatible with the drier and colder months of the year (Fig. 1). When rainfall started again in October 2012, the treatment with PSCU had greater emission, showing a peak of $30 \mathrm{~g} \mathrm{ha}^{-1} \mathrm{~d}^{-1}$ of $\mathrm{N}_{2} \mathrm{O}-\mathrm{N}$, probably because of the gradual release of $\mathrm{N}$ from the fertilizer. The other treatments showed low $\mathrm{N}_{2} \mathrm{O}-\mathrm{N}$ emissions (near $10 \mathrm{~g} \mathrm{ha}^{-1} \mathrm{~d}^{-1}$ ) (Fig. 1).

The $\mathrm{N}_{2} \mathrm{O}$ emissions in the $2012 / 2013$ cycle were low in the first $10 \mathrm{~d}$, similar to those of the previous cycle. The treatment with urea had a peak of $80 \mathrm{~g} \mathrm{ha}^{-1} \mathrm{~d}^{-1}$ of $\mathrm{N}$ on the 14 th day; thereafter, two other periods of high emissions occurred around 20 and $37 \mathrm{~d}$ after fertilizer application after rain events (60 and $40 \mathrm{~g} \mathrm{ha}^{-1} \mathrm{~d}^{-1}$ of $\mathrm{N}_{2} \mathrm{O}-\mathrm{N}$, respectively) (Fig. 2). Polymer and sulfur-coated urea showed lower $\mathrm{N}_{2} \mathrm{O}$ emission than urea in the first $20 \mathrm{~d}$, but after this period the other two peaks of both treatments were similar, and PSCU had higher emissions than all treatments at $40 \mathrm{~d}$ after fertilizer application, probably due to gradual $\mathrm{N}$ release (Fig. 2).

Treatments with NIs showed low $\mathrm{N}_{2} \mathrm{O}-\mathrm{N}$ emissions (around $5 \mathrm{~g} \mathrm{ha}^{-1} \mathrm{~d}^{-1}$ of $\mathrm{N}$ ), similar to the control treatment without $\mathrm{N}$, and did not differ from the treatments where urea with NIs was applied in the same area of the previous year (Fig. 2).

After $217 \mathrm{~d}$ in the 2011/2012 cycle, the cumulative $\mathrm{N}_{2} \mathrm{O}-\mathrm{N}$ emission of the control was equivalent to $1.1 \mathrm{~kg} \mathrm{ha}^{-1}$. The treatment with urea emitted almost $2 \mathrm{~kg} \mathrm{ha}^{-1}$ of $\mathrm{N}_{2} \mathrm{O}-\mathrm{N}$, which corresponded to $0.7 \%$ of total $\mathrm{N}$ applied. The addition of NIs 


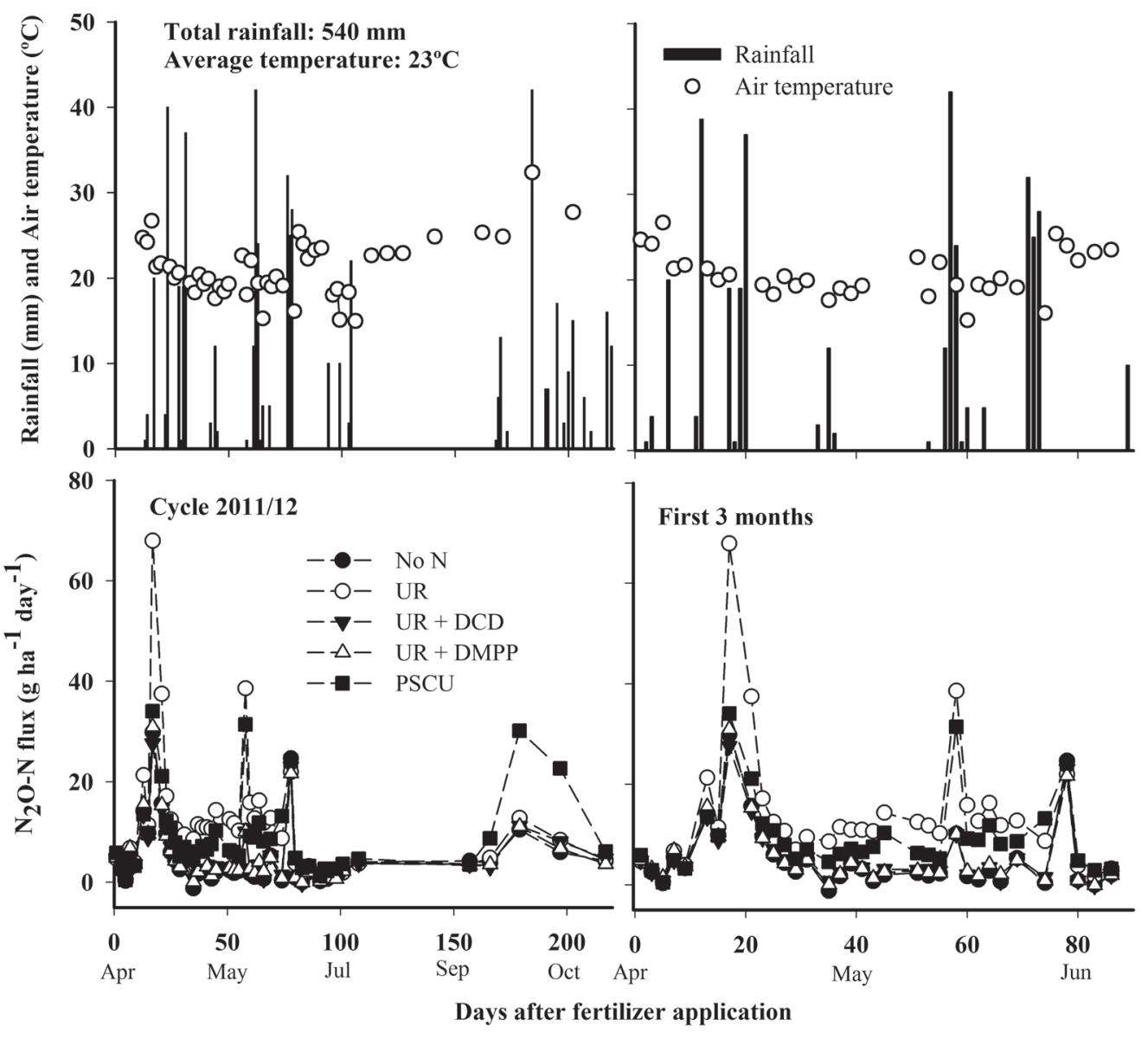

Fig. 1. Rainfall, air temperature, and $\mathrm{N}_{2} \mathrm{O}$ emissions from urea (UR), incorporated in a Red Latosol, with or without nitrification inhibitors (dicyandiamide [DCD] and 3,4-dimethylpyrazole phosphate [DMPP]) or polymer sulfur-coated urea (PSCU) applied to ratoon cane, cycle $2011 / 2012$.

to urea resulted in a strong reduction in $\mathrm{N}_{2} \mathrm{O}$ emissions, which did not differ from those of the control treatment. Controlledrelease fertilizers showed cumulative emissions similar to those of conventional urea (Table 2).

In the second year, the cumulative $\mathrm{N}_{2} \mathrm{O}-\mathrm{N}$ emission in the plots without $\mathrm{N}$ was $600 \mathrm{~g} \mathrm{ha}^{-1}$ after $382 \mathrm{~d}$. Urea treatment produced a $\mathrm{N}_{2} \mathrm{O}-\mathrm{N}$ emission of $1.5 \mathrm{~kg} \mathrm{ha}^{-1}$, which is equivalent to $0.75 \%$ of the total $\mathrm{N}$ applied. Application of PSCU resulted in cumulative $\mathrm{N}_{2} \mathrm{O}$ emission greater than that of conventional urea: almost $2 \mathrm{~kg} \mathrm{ha}^{-1}$ were emitted as $\mathrm{N}_{2} \mathrm{O}-\mathrm{N}$, which represents approximately $1 \%$ of the $\mathrm{N}$ applied. Nitrification inhibitors reduced $\mathrm{N}_{2} \mathrm{O}$ emission from urea by 81 to $100 \%$, which did not differ from the control treatment without $\mathrm{N}$; a similar reduction in $\mathrm{N}_{2} \mathrm{O}$ emissions took place in the plots where the inhibitors were reapplied. There were no differences between DCD and DMPP (Table 3).

\section{Discussion}

Nitrous oxide emissions from plots with no $\mathrm{N}$ fertilizer were 1.1 and $0.6 \mathrm{~kg} \mathrm{ha}^{-1}$ of $\mathrm{N}$ in the first and second seasons, respectively, close to the background emissions values of approximately $1 \mathrm{~kg}^{-1} \mathrm{ha}^{-1} \mathrm{yr}^{-1}$ of $\mathrm{N}_{2} \mathrm{O}-\mathrm{N}$ estimated by Bouwman (1996). Bouwman pointed out that background emissions from agricultural soils are not from a "natural" ecosystem but rather include the effects of crop residues and previous soil amendments. Accordingly, in our study, the soil had been regularly fertilized in previous years. The lower background emissions in the second cycle could be explained by the small amounts of plant residues left on the soil because sugarcane was burned before the harvest in the previous cycle. Sugarcane trash has been shown to increase $\mathrm{N}_{2} \mathrm{O}$ emissions (Vargas et al., 2014).

High daily fluxes of $\mathrm{N}_{2} \mathrm{O}$ were observed for the UR treatment 2 to 3 mo after fertilizer application. Similar results were reported by Carmo et al. (2013) in a sugarcane field in the same region in Brazil. High $\mathrm{N}_{2} \mathrm{O}$ emissions were usually associated with rainfall events, especially in the weeks that followed fertilizer applications. However, after about $100 \mathrm{~d}$ of fertilization, emissions were low for all treatments despite the relatively frequent rains (Fig. 2). Other researchers also showed greater $\mathrm{N}_{2} \mathrm{O}$ emissions in the first weeks after $\mathrm{N}$ fertilizer application, attributing this effect to increased $\mathrm{N}$ availability for nitrification and denitrification processes and favorable environmental conditions for $\mathrm{N}_{2} \mathrm{O}$ emissions such as rainfall, high soil moisture, temperature, and available C (Jumadi et al., 2008; Linzmeier et al., 2001; Menéndez et al., 2006; Signor et al., 2013; Weitz et al., 2001; Zaman et al., 2008).

Cumulative emission of $\mathrm{N}_{2} \mathrm{O}$ in this study was $0.7 \%$ of total $\mathrm{N}$ applied in the treatment with conventional urea. This value is close to the default value of $1 \%$ of the $\mathrm{N}$ applied used by the IPCC (IPCC, 2006) but lower than those of other field studies with sugarcane (Allen et al., 2010; Carmo et al., 2013; Denmead et al., 2010; Signor et al., 2013; Weier et al., 1998). Carmo et al. 

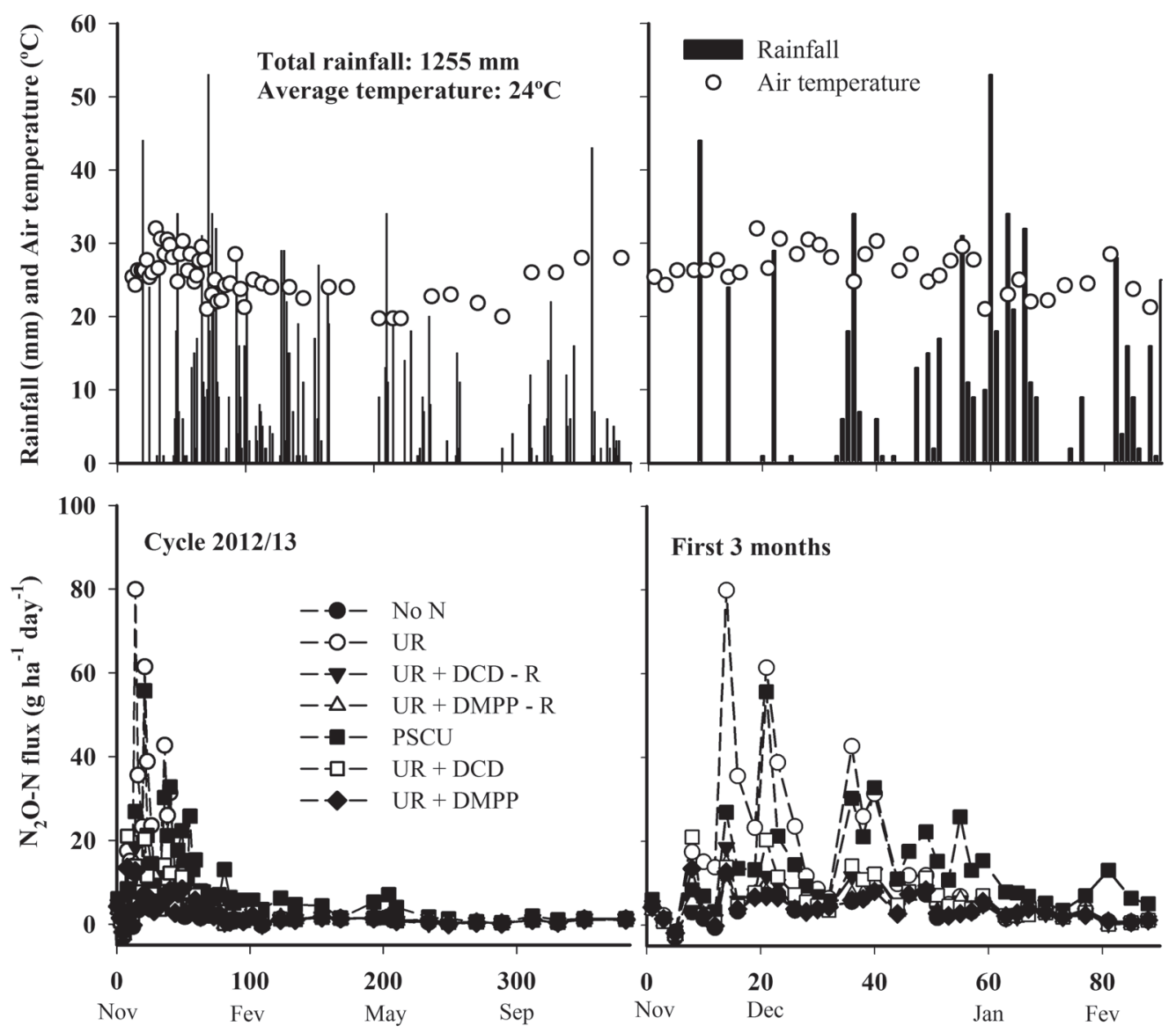

Days after fertilizer application

Fig. 2. Rainfall, air temperature, and $\mathrm{N}_{2} \mathrm{O}$ emissions from urea (UR), incorporated in a Red Latosol, with or without nitrification inhibitors (dicyandiamide [DCD] and 3,4-dimethylpyrazole phosphate [DMPP]) or polymer sulfur-coated urea (PSCU) applied to ratoon cane, cycle 2012/2013. $R$ indicates inhibitor reapplied in same plot of previous cycle.

(2013) found an emission factor of $0.7 \%$ of $\mathrm{N}$ applied as urea in sugarcane fields in Brazil, but the fertilizer emission factor increased to $3 \%$ when vinasse and harvest trash were present. Lisboa et al. (2011) also listed several studies with sugarcane with a mean emission factor of 3.9\% (values of 2.0-29\%; background values were not subtracted). As in the present study, other studies in Brazil have reported $\mathrm{N}_{2} \mathrm{O}$ emission factors lower than the IPCC default value. This has been attributed to the high

Table 2. Cumulative nitrous oxide emissions for $217 \mathrm{~d}$ from urea, incorporated in the Red Latosol, with or without nitrification inhibitors (dicyandiamide and 3,4-dimethylpyrazole phosphate) or polymer and sulfur-coated urea applied to ratoon cane, 2011/2012.

\begin{tabular}{lccc}
\hline Treatments & \multicolumn{2}{c}{$\begin{array}{c}\text { Cumulative } \mathrm{N}_{2} \mathrm{O}-\mathrm{N} \\
\text { emissions }\end{array}$} & $\begin{array}{c}\text { Differences from } \\
\text { ureaी }\end{array}$ \\
\hline No N (control) & $\mathrm{g} \mathrm{ha}^{-1} \neq$ & $\%$ of N applied§ & $\%$ \\
UR & $1098 \mathrm{~b}$ & - & - \\
UR+DCD & $1924 \mathrm{a}$ & 0.69 & - \\
UR+DMPP & $1142 \mathrm{~b}$ & 0.04 & -95 \\
PSCU & $1112 \mathrm{~b}$ & 0.01 & -98 \\
\hline
\end{tabular}

† DCD, dicyandiamide; DMPP, 3,4-dimethylpyrazole phosphate; PSCU, polymer and sulfur-coated urea; UR, urea.

₹ Values followed by the same lowercase letter are not significantly different at $P \leq 0.05$ using the Tukey test.

$\S$ Results from treatment without $\mathrm{N}$ were subtracted for this calculation.

I (-) reduction, (+) increase; coefficient of variation: $15 \%$. drainage capacity of Oxisols, which prevent water accumulation in the soil profile for extended periods of time (de Morais et al., 2013; Jantalia et al., 2008).

The default value of the IPCC (IPCC, 2001) for reduction of $\mathrm{N}_{2} \mathrm{O}$ emission due to the use of enhanced-efficiency fertilizers

Table 3. Cumulative nitrous oxide emissions for $382 \mathrm{~d}$ from urea, incorporated in the Red Latosol, with or without nitrification inhibitors (dicyandiamide and 3,4-dimethylpyrazole phosphate) or polymer sulfur coated-urea applied to ratoon cane 2012/2013.

\begin{tabular}{lccc}
\hline Treatmentst & \multicolumn{2}{c}{$\begin{array}{c}\text { Cumulative } \mathrm{N}_{2} \mathrm{O}-\mathrm{N} \\
\text { emissions }\end{array}$} & $\begin{array}{c}\text { Differences from } \\
\text { ureaf }\end{array}$ \\
\hline No N (control) & 9 ha $^{-1} \neq$ & $\%$ of N applied§ & $\%$ \\
UR & $587 \mathrm{c}$ & - & - \\
UR+DCD-R & $1484 \mathrm{~b}$ & 0.75 & - \\
UR+DMPP-R & $674 \mathrm{c}$ & 0.07 & -90 \\
UR+DCD & $643 \mathrm{c}$ & 0.05 & -94 \\
UR+DMPP & $759 \mathrm{c}$ & 0.14 & -81 \\
PSCU & $584 \mathrm{c}$ & 0.00 & -100 \\
\hline
\end{tabular}

† DCD, dicyandiamide; DMPP, 3,4-dimethylpyrazole phosphate; PSCU, polymer and sulfur-coated urea; $R$, inhibitor reapplied in same plot of previous cycle; UR, urea.

\# Values followed by the same lowercase letter are not significantly different at $P \leq 0.05$ using the Tukey test.

$\S$ Results from treatment without $\mathrm{N}$ were subtracted for this calculation. ๆ (-) reduction, (+) increase; coefficient of variation: $17 \%$. 
is $30 \%$. Results presented in this study showed much higher reductions: NIs lowered $\mathrm{N}_{2} \mathrm{O}$ emission from urea by $90 \%$, as a mean of two seasons, which is in the upper limit of the values compiled by Snyder et al. (2009). These researchers listed decreases in the $\mathrm{N}_{2} \mathrm{O}$ emission ranging from 40 to $96 \%$ with the addition of NIs to conventional $\mathrm{N}$ fertilizers.

The variation in $\mathrm{N}_{2} \mathrm{O}$ reduction caused by NIs is explained by the complex combination of factors that affect the action of such compounds in the soils and the drivers of $\mathrm{N}_{2} \mathrm{O}$ emission (e.g., soil $\mathrm{pH}$, organic matter, porosity, temperature, and soil moisture) (Halvorson et al., 2014; Singh et al., 2008; Subbarao et al., 2006; Trenkel, 2010; Vargas et al., 2014; Weiske et al., 2001). For example, Singh et al. (2008) showed $90 \%$ reduction in $\mathrm{N}_{2} \mathrm{O}$ emissions by the addition of DCD in urine to a soil with low organic carbon $\left(3.4 \mathrm{~g} \mathrm{~kg}^{-1}\right)$, but the reduction decreased to $45 \%$ when applied to a soil with high organic carbon $\left(8 \mathrm{~g} \mathrm{~kg}^{-1}\right)$ in $60 \mathrm{~d}$ of measurement. In this way, depending on environmental conditions and site characteristics, the nitrification inhibitor is degraded in soil faster than plants can take up $\mathrm{NH}_{4}^{+}$, thus increasing $\mathrm{N}_{2} \mathrm{O}$ emissions after the period during which NIs are effective (Hu et al., 2013; Jumadi et al., 2008; Liu et al., 2013; Weiske et al., 2001).

Sugarcane is a fast-growing plant, capable of accumulating between 30 and $60 \mathrm{tha}^{-1}$ of dry matter in one season (Cantarella et al., 2012). The demand of $\mathrm{N}$ is high during the initial stages of ratoon growth (Franco et al., 2011). In 2011/2012, the fertilizers were applied at the end of the summer when plants were already $1.5 \mathrm{~m}$ tall and growing fast; in 2012/2013, N was applied $15 \mathrm{~d}$ after harvest, at the end of the spring but during a period that was warm and rainy enough (Fig. 2) for fast plant growth. Therefore, even if the NIs did not have a lasting inhibitory effect because of the high soil temperatures, the $\mathrm{NH}_{4}^{+}$preserved as a consequence of lower nitrification rate would have a fair chance of being readily taken up by the sugarcane plants. This may explain the high efficiency of both NIs in reducing $\mathrm{N}_{2} \mathrm{O}$ emission in the present study.

The sugarcane harvesting season spans from April to November in Brazil. From April to September (late fall to early spring in the southern hemisphere), rainfall is somewhat scarce, and temperatures are mild for sugarcane development and, thus, for $\mathrm{N}$ uptake. It is not possible to foresee whether NIs will show the same effectiveness to reduce $\mathrm{N}_{2} \mathrm{O}$ emission if applied in these drier months as compared with the results reported here. Because of the long harvesting season, many fields are fertilized in the dry months; therefore, the study of NIs under such conditions deserves attention.

Reapplication of NIs on the same site of the previous year did not affect the capacity of DCD or DMPP to reduce $\mathrm{N}_{2} \mathrm{O}$ losses (Table 3). Rajbanshi et al. (1992) showed that DCD was degraded faster in soils after reapplication, which could decrease its effectiveness to inhibit $\mathrm{NH}_{4}^{+}$oxidation. However, the interval between reapplications was shorter than the $1 \mathrm{yr}$ used in our study. Other researchers have reported opposite results, indicating that reapplication of DCD after $57 \mathrm{~d}$ (Wakelin et al., 2013) or repeated application over a 3-yr period (Weiske et al., 2001) did not affect the persistence of the NIs. Therefore, most results indicate that the continuous use of NIs poses no risk of decreased efficiency to reduce $\mathrm{N}_{2} \mathrm{O}$ emission.
Dicyandiamide and DMPP showed similar capacities to reduce $\mathrm{N}_{2} \mathrm{O}$ emissions (Table 3). Weiske et al. (2001) showed that DMPP was more efficient than DCD because DCD was degraded in soil faster than DMPP. Subbarao et al. (2006) pointed out that the mobility of DCD in soil was higher than that of $\mathrm{NH}_{4}^{+}$, whereas the relative mobility of DMPP is about the same as $\mathrm{NH}_{4}^{+}$, which may make DMPP more effective than DCD. However, in the present study both NIs were very efficient in mitigating $\mathrm{N}_{2} \mathrm{O}$ emissions, probably due to favorable environmental conditions.

The controlled release fertilizer used in this study failed to reduce $\mathrm{N}_{2} \mathrm{O}$ emissions as compared with urea. This was somewhat unexpected, although it is not a new finding in the literature. In the second experiment, $\mathrm{N}_{2} \mathrm{O}$ emissions of PSCU were even higher than those of the regular UR (Table 3). The reasons for these results are not clear. Under laboratory conditions we observed that $\mathrm{N}$ from PSCU was not readily released and that the two coating layers remained mostly intact for at least $50 \mathrm{~d}$ (unpublished results). The gradual release of $\mathrm{N}$ prevents peaks of nutrient concentration above the capacity of plants to take it up, reducing the $\mathrm{N}$ available for microbial processes of nitrification and denitrification that lead to $\mathrm{N}_{2} \mathrm{O}$ emissions (Delgado and Mosier, 1996). Increasing the rate of $\mathrm{N}$ application, depending on soil $\mathrm{C}$ availability, may exponentially increase $\mathrm{N}_{2} \mathrm{O}$ emission (Kim et al., 2013). Thus, slow $\mathrm{N}$ release from CRFs or split application of $\mathrm{N}$ can reduce $\mathrm{N}_{2} \mathrm{O}$ emissions depending of environmental conditions and product properties (Akiyama et al., 2010; Burton et al., 2008; Halvorson et al., 2014; Hyatt et al., 2010; Yang et al., 2012).

The complex interactions of time of $\mathrm{N}$ release of CRFs, environmental conditions, and $\mathrm{N}$ uptake by plants can affect the amounts of nutrient in the soil and, therefore, the risks of $\mathrm{N}_{2} \mathrm{O}$ fluxes to the atmosphere (Venterea et al., 2012). In the first year, the $\mathrm{N}$ fertilizer treatments were applied in April, at the end of the rainy season. Nitrous oxide emissions of the plots with PSCU were lower than those of conventional UR in the first $60 \mathrm{~d}$ (Fig. 1), when probably less $\mathrm{N}$ from the PSCU was available. However, after the dry season (i.e., in October), a peak of $\mathrm{N}_{2} \mathrm{O}$ emission (Fig. 1) indicates that the $\mathrm{N}$ that remained in the granules of PSCU probably had been let out. In the second year, the fertilizers were applied before the long, hot, and rainy summer, and the $\mathrm{N}$ from PSCU probably was released sooner: at about $40 \mathrm{~d}$ after fertilization, the $\mathrm{N}_{2} \mathrm{O}$ emissions from the PSCU treatments prevailed over those of UR (Fig. 2). Therefore, the chain of events controlling $\mathrm{N}$ release from PSCU did not favor this $\mathrm{N}$ source, and, ultimately, the cumulative emissions of $\mathrm{N}_{2} \mathrm{O}$ from PSCU were similar or higher than those of UR.

Other researchers have also reported situations in which $\mathrm{N}_{2} \mathrm{O}$ emissions from soils treated with slow- or controlled-release $\mathrm{N}$ fertilizers were similar to those of readily available $\mathrm{N}$ sources (Delgado and Mosier, 1996; Halvorson et al., 2014; Hu et al., 2013; Jumadi et al., 2008; Venterea et al., 2011), mainly because of the lack of synchrony of $\mathrm{N}$ release and plant use.

In the present study, we conducted intense measurements of $\mathrm{N}_{2} \mathrm{O}$ emissions for two consecutive seasons to compare emissions derived from a conventional $\mathrm{N}$ fertilizer (urea) with those of urea amended with two NIs and that of a CRF. Our results indicated a smaller $\mathrm{N}_{2} \mathrm{O}$ emission factor for the conventional fertilizer than most results reported in the international literature for sugarcane, 
suggesting that $\mathrm{N}_{2} \mathrm{O}$ emissions from highly permeable Oxisols in this region of Brazil may be lower than from most other soils. We also demonstrated that NIs sharply decreased $\mathrm{N}_{2} \mathrm{O}$ emissions but that the CRF was ineffective at reducing $\mathrm{N}_{2} \mathrm{O}$ emissions. Our results are among the first in the literature to test these classes of compounds in tropical soils and in sugarcane in particular. The effectiveness of NIs to reduce $\mathrm{N}_{2} \mathrm{O}$ emissions in sugarcane must be tested further, including when fertilizer is applied in the dryer months of the year and in combination with vinasse and trashcommon practices in most sugarmills-which substantially increase $\mathrm{N}_{2} \mathrm{O}$ emissions (Carmo et al., 2013).

There is growing interest of the international community in data of GHG emissions in sugarcane used for bioethanol from Brazil because soil emissions of $\mathrm{N}_{2} \mathrm{O}$ are an important component of calculated net GHG emissions from ethanol production (Boddey et al., 2008; Macedo et al., 2008). Therefore, NIs may be an option to increase sugarcane ethanol sustainability indicators. There are indications that sugarcane prefers $\mathrm{NH}_{4}^{+}$over $\mathrm{NO}_{3}{ }^{-}$in mineral nutrition (DeArmas et al., 1992; Parashar et al., 1980), which could further justify the use of NIs. However, NIs are not commonly used in Brazil because they add cost to fertilizers and because these products do not always bring yield increases (Trenkel, 2010), especially in situations where $\mathrm{N}$ loss by nitrate leaching is low. Cantarella (2007), Ghiberto et al. (2009), and Ghiberto et al. (2011) observed very little $\mathrm{NO}_{3}{ }^{-}$leaching from $\mathrm{N}$ fertilizers in sugarcane using fertilizers labeled with ${ }^{15} \mathrm{~N}$. Although losses of $\mathrm{N}$ as $\mathrm{N}_{2} \mathrm{O}$ are environmentally important, they are a small fraction of fertilizer costs, and sugarcane growers may not be willing to pay the cost of NIs if no yield increases accompany this environmental benefit. Mitigating $\mathrm{N}_{2} \mathrm{O}$ emissions from agriculture may, therefore, require broader approaches, such as the internationalization of costs of GHG abatement (Cavigelli et al., 2012; Venterea et al., 2012), in addition to the technical solutions found by researchers.

\section{Acknowledgments}

The authors thank Dr. Regina C.M. Pires for help with the experimental area and Mario H.F.S. Lunetta, Romildo Bonaretti, and Juliana M. Natividade for technical assistance. This research was supported by CAPES and FAPESP-BIOEN- project 2008/56147-1. This work resulted from a conference supported by NSF Research Coordination Network award DEB-1049744 and by the Soil Science Society of America, the American Geophysical Union, The International Plant Nutrition Institute, The Fertilizer Institute, and the International Nitrogen Initiative.

\section{References}

Akiyama, H., X. Yan, and K. Yagi. 2010. Evaluation of effectiveness of enhancedefficiency fertilizers as mitigation options for $\mathrm{N}_{2} \mathrm{O}$ and $\mathrm{NO}$ emissions from agricultural soils: Meta-analysis. Glob. Change Biol. 16:1837-1846. doi:10.1111/j.1365-2486.2009.02031.x

Allen, D.E., G. Kingston, H. Rennenberg, R.C. Dalal, and S. Schmidt. 2010. Effect of nitrogen fertilizer management and waterlogging on nitrous oxide emission from subtropical sugarcane soils. Agric. Ecosyst. Environ. 136:209-217. doi:10.1016/j.agee.2009.11.002

Alves, B., K.A. Smith, R.A. Flores, A.S. Cardoso, W.R.D. Oliveira, C.P.Jantalia, S. Urquiaga, and R.M. Boddey. 2012. Selection of the most suitable sampling time for static chambers for the estimation of daily mean $\mathrm{N}_{2} \mathrm{O}$ flux from soils. Soil Biol. Biochem. 46:129-135. doi:10.1016/j.soilbio.2011.11.022

Boddey, R.M., R.L.B. Soares, B.J.R. Alves, and S. Urquiaga. 2008. Bio-ethanol production in Brazil. In: D. Pimentel, editor, Biofuels, solar and wind as renewable energy systems. Springer, New York. p. 321-356.

Bouwman, A.F. 1996. Direct emission of nitrous oxide from agricultural soils. Nutr. Cycl. Agroecosyst. 46:53-70. doi:10.1007/BF00210224
Burton, D.L., B.J. Zebarth, K.M. Gillam, and J.A. MacLeod. 2008. Effect of split application of fertilizer nitrogen on $\mathrm{N}_{2} \mathrm{O}$ emissions from potatoes. Can. J. Soil Sci. 88:229-239. doi:10.4141/CJSS06007

Camargo, O.A., A.C. Moniz, J.A. Jorge, and J.M. Valadares. 1986. Methods of soil chemical, physical, and mineralogical analysis of the Agronomic Institute in Campinas. Instituto Agronômico, Campinas, Brazil. (In Portuguese.)

Cantarella, H. 2007. Nitrogen. In: R.F. Novais, et al., editors, Soil fertility. Sociedade Brasileira de Ciência do Solo, Viçosa, Brazil. p. 375-470. (In Portuguese.)

Cantarella, H., M.S. Buckeridge, M.A. Van Sluys, A.P. Souza, A.A.F. Garcia, M.Y. Nishiyama, Jr., R. Maciel Filho, C.H.B Cruz, and G.M. Souza. 2012. Sugarcane. In: C. Kole et al., editors, Handbook of bioenergy crop plants. CRC Press, Boca Raton, FL. p. 523-561.

Carmo, J.B., S. Filoso, L.C. Zotelli, E.R.S. Neto, L.M. Pitombo, P.J. Duarte-Neto, V.P. Vargas, C.A. Andrade, G.J.C. Gava, R. Rossetto, H. Cantarella, A.E. Neto, and L.A. Martinelli. 2013. Infield greenhouse gas emissions from sugarcane soils in Brazil: Effects from synthetic and organic fertilizer application and crop trash accumulation. GCB Bioenergy 5:267-280. doi:10.1111/j.1757-1707.2012.01199.x

Cavigelli, M.A., S.J.D. Grosso, M.A. Liebig, C.S. Snyder, P.E. Fixen, R.T. Venterea, A.B. Leytem, J.E. McLain, and D.B. Watts. 2012. US agricultural nitrous oxide emissions: Context, status, and trends. Front. Ecol. Environ 10:537-546. doi:10.1890/120054

Cerri, C.C., S.M.F. Maia, M.V. Galdos, C.E.P. Cerri, B.J. Feigl, and M. Bernoux. 2009. Brazilian greenhouse gas emissions: The importance of agriculture and livestock. Sci. Agric. 66:831-843. doi:10.1590/ S0103-90162009000600017

Chien, S.H., L.I. Prochnow, and H. Cantarella. 2009. Recent developments of fertilizer production and use to improve nutrient efficiency and minimize environmental impacts. Adv. Agron. 102:267-322. doi:10.1016/ S0065-2113(09)01008-6

Crutzen, P.J., A.R. Mosier, K.A. Smith, and W. Winiwarter. 2008. $\mathrm{N}_{2} \mathrm{O}$ release from agro bio-fuel production negates global warming reduction by replacing fossil fuels. Atmos. Chem. Phys. 8:389-395. doi:10.5194/ acp-8-389-2008

DeArmas, R., M.H. Valadier, M.L. Champigny, and T. Lamaze. 1992. Influence of ammonium and nitrate on the growth and photosynthesis of sugarcane. J. Plant Physiol. 140:531-535. doi:10.1016/S0176-1617(11)80783-2

Delgado, J.A., and A.R. Mosier. 1996. Mitigation alternatives to decrease nitrous oxides emissions and urea-nitrogen loss and their effect on methane flux. J. Environ. Qual. 25:1105-1111. doi:10.2134/ jeq1996.00472425002500050025x

de Morais, R.F., R.M. Boddey, S. Urquiaga, C.P. Jantalia, and B.J.R. Alves. 2013. Ammonia volatilization and nitrous oxide emissions during soil preparation and $\mathrm{N}$ fertilization of elephant grass (Pennisetum purpureum Schum.). Soil Biol. Biochem. 64:80-88. doi:10.1016/j.soilbio.2013.04.007

Denmead, O.T., B.C.T. Macdonald, G. Bryant, T. Naylor, S. Wilson, D.W.T. Griffith, W.J. Wangd, B. Salter, I. White, and P.W. Moody. 2010. Emissions of methane and nitrous oxide from Australian sugarcane soils. Agric. For. Meteorol. 150:748-756. doi:10.1016/j.agrformet.2009.06.018

Eichner, M.J. 1990. Nitrous oxide emissions from fertilized soils: Summary of available data. J. Environ. Qual. 19:272-280. doi:10.2134/ jeq1990.00472425001900020013x

Empresa Brasileira de Pesquisa Agropecuária. 2006. Brazilian soil classification system. Empresa Brasileira de Pesquisa Agropecuária, Rio de Janeiro, Brazil. (In Portuguese.)

Franco, H.C.J., R. Otto, C.E. Faroni, A.C. Vitti, E.C.A. Oliveira, and P.C.O. Trivelin. 2011. Nitrogen in sugarcane derived from fertilizer under Brazilian field conditions. Field Crops Res. 121:29-40. doi:10.1016/j. fcr.2010.11.011

Galdos, M.V., C.C. Cerri, R. Lal, M. Bernoux, B. Feigl, and C.E.P. Cerri. 2010. Net greenhouse gas fluxes in Brazilian ethanol production systems. GCB Bioenergy 2:37-44. doi:10.1111/j.1757-1707.2010.01037.x

Ghiberto, P.J., P.L. Libardi, A.S. Brito, and P.C.O. Trivelin. 2009. Leaching of nutrients from a sugarcane crop growing on an Ultisol in Brazil. Agric. Water Manage. 96:1443-1448. doi:10.1016/j.agwat.2009.04.020

Ghiberto, P.J., P.L. Libardi, A.S. Brito, and P.C.O. Trivelin. 2011. Nitrogen fertilizer leaching in an Oxisol cultivated with sugarcane. Sci. Agric. 68:86-93. doi:10.1590/S0103-90162011000100013

Halvorson, A.D., C.S. Snyder, A.D. Blaylock, and S.J. Del Grosso. 2014. Enhancedefficiency nitrogen fertilizers: Potential role in nitrous oxide emission mitigation. Agron. J. 106:715-722. doi:10.2134/agronj2013.0081

Hu, X.-K., F. Su, X.-T. Ju, B. Gao, O. Oenema, P. Christie, B.-X. Huang, R.-F. Jiang, and F.-S. Zhang. 2013. Greenhouse gas emissions from a wheatmaize double cropping system with different nitrogen fertilization regimes. Environ. Pollut. 176:198-207. doi:10.1016/j.envpol.2013.01.040 
Hutchinson, G.L., and A.R. Mosier. 1981. Improved soil cover method for field measurement of nitrous oxide fluxes. Soil Sci. Soc. Am. J. 45:311-316. doi:10.2136/sssaj1981.03615995004500020017x

Hyatt, C.R., R.T. Venterea, C.J. Rosen, M. McNearney, M.L. Wilson, and M.S. Dolan. 2010. Polymer-coated urea maintains potato yields and reduces nitrous oxide emissions in a Minnesota loamy sand. Soil Sci. Soc. Am. J. 74:419-428. doi:10.2136/sssaj2009.0126

Intergovernmental Panel on Climate Change (IPCC). 2001. Technological and economic potential of greenhouse gas emissions reduction. Working group III: Mitigation, third assessment report. Climate Change 2001. http:// www.grida.no/publications/other/ipcc_tar/ (accessed 12 Apr. 2014).

Intergovernmental Panel on Climate Change (IPCC). 2006. Guidelines for national greenhouse gas inventories, 2006. http://www.ipcc-nggip.iges. or.jp/public/2006gl/index.html (accessed 12 Apr. 2014).

Intergovernmental Panel on Climate Change (IPCC). 2007. Working group I report "The physical science basis": Fourth assessment report. Climate Change 2007. http://www.ipcc.ch/publications_and_data/ar4/wg1/en/ contents.html (accessed 12 Apr. 2014).

Jantalia, C.P., H.P. dos Santos, S. Urquiaga, R.M. Boddey, and B.J.R. Alves. 2008. Fluxes of nitrous oxide from soil under different crop rotations and tillage systems in the south of Brazil. Nutr. Cycl. Agroecosyst. 82:161-173. doi:10.1007/s10705-008-9178-y

Jumadi, O., Y. Hala, A. Muis, A. Ali, M. Palennari, K. Yagi, and K. Inubushi. 2008. Influences of chemical fertilizers and a nitrification inhibitor on greenhouse gas fluxes in a corn (Zea mays L.) field in Indonesia. Microbes Environ. 23:29-34. doi:10.1264/jsme2.23.29

Kim, D.G., G.H. Ramirez, and D. Giltrap. 2013. Linear and nonlinear dependency of direct nitrous oxide emissions on fertilizer nitrogen input: A meta-analysis. Agric. Ecosyst. Environ. 168:53-65. doi:10.1016/j. agee.2012.02.021

Linzmeier, W., R. Gutser, and U. Shmidhalter. 2001. Nitrous oxide emission from soil and from a nitrogen-15-labelled fertilizer with the new nitrification inhibitor 3,4-dimethylpyrazole phosphate (DMPP). Biol. Fertil. Soils 34:103-108. doi: $10.1007 / \mathrm{s} 003740100383$

Lisboa, C.C., K. Butterbach-Bahl, M. Mauder, and R. Kiese. 2011. Bioethanol production from sugarcane and emissions of greenhouse gases: Known and unknowns. GCB Bioenergy 3:277-292. doi:10.1111/j.1757-1707.2011.01095.x

Liu, C., K. Wang, and X. Zheng. 2013. Effects of nitrification inhibitors (DCD and DMPP) on nitrous oxide emission, crop yield and nitrogen uptake in a wheat-maize cropping system. Biogeosciences 10:2427-2437. doi: 10.5194/bg-10-2427-2013

Macedo, I.C., J.E.A. Seabra, and J.E.A.R. Silva. 2008. Green house gases emissions in the production and use of ethanol from sugarcane in Brazil: The 2005/2006 averages and a prediction for 2020. Biomass Bioenergy 32:582-595. doi:10.1016/j.biombioe.2007.12.006

Mathieu, O., J. Lévêque, C. Henault, M.J. Milloux, F. Bizouard, and F. Andeux. 2006. Emissions and spatial variability of $\mathrm{N}_{2} \mathrm{O}, \mathrm{N}_{2}$ and nitrous oxide mole fraction at the field scale, revealed with $15 \mathrm{~N}$ isotopic techniques. Soil Biol. Biochem. 38:941-951. doi:10.1016/j.soilbio.2005.08.010

Menéndez, S., P. Merino, M. Pinto, C. González-Murua, and J.M. Estavillo. 2006. 3,4-dimethylpyrazol phosphate effect on nitrous oxide, nitric oxide, ammonia, and carbon dioxide emissions from grasslands. J. Environ. Qual. 35:973-981. doi:10.2134/jeq2005.0320

Ministério de Ciência, Tecnologia e Inovação (MCTI). 2013. Annual estimates of greenhouse gases emissions in Brazil. (In Portuguese.) http://www.mct. gov.br/index.php/content/view/347281.html (accessed 6 May 2014).

Mosier, A.R., A.D. Halvorson, C.A. Reule, and X.J. Liu. 2006. Net global warming potential and greenhouse gas intensity in irrigated cropping systems in northeastern Colorado. J. Environ. Qual. 35:1584-1598. doi: $10.2134 /$ jeq2005.0232

Parashar, K.S., R. Prasad, R.P. Sharma, S.N. Sharma, and S. Singh. 1980. Efficiency of urea, nitrification inhibitor treated urea and slow release nitrogen fertilizers for sugarcane. Z. Pflanzenernaehr. Bodenkd. 143:262267. doi:10.1002/jpln.19801430303

Rajbanshi, S.S., G. Benckiser, and J.C.G. Ottow. 1992. Effect of concentration, incubation temperature, and repeated applications on degradation kinetics of dicyandiamide (DCD) in model experiments with a silt loam soil. Biol. Fertil. Soils 13:61-64. doi:10.1007/BF00337336

Rochette, P., and N.S. Ericksen-Hamel. 2008. Chamber measurements of soil nitrous oxide flux: Are absolute values reliable? Soil Sci. Soc. Am. J. 72:331-342. doi:10.2136/sssaj2007.0215

Signor, D., C.E.P. Cerri, and R. Conant. 2013. $\mathrm{N}_{2} \mathrm{O}$ emissions due to nitrogen fertilizer applications in two regions of sugarcane cultivation in Brazil. Environ. Res. Lett. 8:015013. doi:10.1088/1748-9326/8/1/015013
Singh, J., S. Saggar, D.L. Giltrap, and N.S. Bolan. 2008. Decomposition of dicyandiamide (DCD) in three contrasting soils and its effects in nitrous oxide emission, soil respiratory activity, and microbial biomass: An incubatory study. Aust. J. Soil Res. 46:517-525. doi:10.1071/SR07204

Snyder, C.S., T.W. Bruulsema, T.L. Jensen, and P.E. Fixen. 2009. Review of greenhouse gas emissions from crop production systems and fertilizer management effects. Agric. Ecosyst. Environ. 133:247-266. doi:10.1016/j. agee.2009.04.021

Soares, J.R., H. Cantarella, and M.C.L. Menegale. 2012. Ammonia volatilization losses of surface-applied urea with urease and nitrification inhibitors. Soil Biol. Biochem. 52:82-89. doi:10.1016/j.soilbio.2012.04.019

Stevens, R.J., and R.J. Laughlin. 1998. Measurement of nitrous oxide and di-nitrogen emissions from agricultural soils. Nutr. Cycl. Agroecosyst. 52:131-139. doi:10.1023/A:1009715807023

Subbarao, G.V., O. Ito, K.L. Sahrawat, W.L. Berry, K. Nakahara, T. Ishikawa, T. Watanabe, K. Suenaga, M. Rondon, and I.M. Rao. 2006. Scope and strategies for regulation of nitrification in agricultural system: Challenges and opportunities. Crit. Rev. Plant Sci. 25:303-335. doi: $10.1080 / 07352680600794232$

Systat Software. 2006. SSI. Sigmaplot for Windows, version 10. Systat Software, San Jose, CA.

Trenkel, M.E. 2010. Slow- and controlled-release and stabilized fertilizers: An option for enhancing nutrient efficiency in agriculture. International Fertilizer Industry Association, Paris. http://www.fertilizer.org/ItemDeta il ?iProductCode=9137Pdf\&Category=AGRI\&WebsiteKey=41 1e97244bda-422f-abfc-8152ed74f306 (accessed 15 July 2014).

van Raij, B., J.C. Andrade, H. Cantarella, and J.A. Quaggio. 2001. Chemical analysis for evaluation of fertility of tropical soils. Instituto Agronômico, Campinas, Brazil. (In Portuguese.)

van Raij, B., H. Cantarella, J.A. Quaggio, and A.M.C. Furlani. 1997. Fertilization and liming recommendations for Sao Paulo state. Boletim Técnico 100-Instituto Agronômico. Instituto Agronômico, Campinas, Brazil. (In Portuguese.)

Vargas, V.P., H. Cantarella, A.A. Martins, J.R. Soares, J.B. Carmo, and C.A. Andrade. 2014. Sugarcane crop residue increases $\mathrm{N}_{2} \mathrm{O}$ and $\mathrm{CO}_{2}$ emissions under high soil moisture conditions. Sugar Tech 16:174-179. doi:10.1007/s12355-013-0271-4

Venterea, R.T., A.D. Halvorson, N. Kitchen, M.A. Liebig, M.A. Cavigelli, S.J.D. Grosso, P.P. Motavalli, K.A. Nelson, K.A. Spokas, B.P. Singh, C.E. Stewart, A. Ranaivoson, J. Strock, and H. Collins. 2012. Challenges and opportunities for mitigating nitrous oxide emissions from fertilized cropping systems. Front. Ecol. Environ 10:562-570. doi:10.1890/120062

Venterea, R.T., B. Maharjan, and M.S. Dolan. 2011. Fertilizer source and tillage effects on yield-scaled nitrous oxide emissions in a corn cropping system. J. Environ. Qual. 40:1521-1531. doi:10.2134/jeq2011.0039

Wakelin, S.A., T.J. Clough, E.M. Gerard, and M. O'Callaghan. 2013. Impact of short-interval, repeat application of dicyandiamide on soil $\mathrm{N}$ transformation in urine patches. Agric. Ecosyst. Environ. 167:60-70. doi:10.1016/j.agee.2013.01.007

Weier, K.L., D.E. Rolston, and P.J. Thorburn. 1998. The potential for N losses via denitrification beneath a green cane trash blanket. Proc. Australian Soc. Sugar Cane Technol. 20:169-175.

Weiske, A., G. Benckiser, T. Herbert, and J.C.G. Ottow. 2001. Influence of nitrification inhibitor 3,4-dimethylpyrazole phosphate (DMPP) in comparison with dicyandiamide (DCD) on nitrous oxide emissions, carbon dioxide fluxes and methane oxidation during 3 years of repeated application in field experiments. Biol. Fertil. Soils 34:109-117. doi: $10.1007 / \mathrm{s} 003740100386$

Weitz, A.M., E. Linder, S. Frolking, P.M. Crill, and M. Keller. 2001. $\mathrm{N}_{2} \mathrm{O}$ emissions from humid tropical agricultural soils: Effects of soil moisture, texture and nitrogen availability. Soil Biol. Biochem. 33:1077-1093. doi:10.1016/S0038-0717(01)00013-X

Yang, J., G. Liu, J. Ma, H. Xu, and K. Yagi. 2012. Effect of controlled-release fertilizer on nitrous oxide emission from a winter wheat field. Nutr. Cycl. Agroecosyst. 94:111-122. doi:10.1007/s10705-012-9532-y

Zaman, M., M.L. Nguyen, J.D. Blennerhassett, and B.F. Quin. 2008. Reducing $\mathrm{NH}_{3}, \mathrm{~N}_{2} \mathrm{O}$ and $\mathrm{NO}_{3}-\mathrm{N}$ losses from a pasture soil with urease or nitrification inhibitors and elemental S-amended nitrogenous fertilizers. Biol. Fertil. Soils 44:693-705. doi:10.1007/s00374-007-0252-4 